\title{
MIR19A Pre-miRNA
}

National Cancer Institute

\section{Source}

National Cancer Institute. MIR19A Pre-miRNA. NCI Thesaurus. Code C82708.

MIR19A pre-miRNA is an oligonucleotide that is encoded by the human MIR19A gene and has a role in the regulation of gene expression. 